\title{
Sanitizing action of triple-strength vinegar against Escherichia coli on lettuce
}

\author{
Giovanna C Souza; Wilma A Spinosa; Tereza CRM Oliveira ${ }^{1}$
}

'Universidade Estadual de Londrina (UEL), Londrina-PR, Brazil; giovannacavagnari@hotmail.com; wilma.spinosa@gmail.com; terezaoliveira@yahoo.com.

\begin{abstract}
Vegetable sanitization protocols recommend the use of chlorine, which has adverse effects on the environment and carcinogenic effects on humans. Acetic acid is an interesting alternative to chlorine because it possesses no risk to human health and is widely available in the form of vinegar. This study aimed to evaluate the sanitizing action of vinegar, $130 \mathrm{~g} \mathrm{~L}^{-1}$ total titratable acidity expressed as acetic acid, on lettuce. Vinegar was chosen because it is a low-cost product widely available in the Brazilian market. The minimum inhibitory concentration and minimum bactericidal concentration of vinegar against Escherichia coli were 2.5 and $15 \mathrm{~g} \mathrm{~L}^{-1}$ total acidity, respectively. Lettuce leaves artificially contaminated with $E$. coli or naturally contaminated with total coliforms were washed with water and immersed in vinegar solution ( $15 \mathrm{~g} \mathrm{~L}^{-1}$ total acidity) for $15 \mathrm{~min}$. This period was sufficient to reduce $E$. coli counts in artificially contaminated samples and total coliforms in naturally contaminated samples. There were no visual changes in lettuce leaves, which indicates that vinegar at $15 \mathrm{~g} \mathrm{~L}^{-1}$ total acidity can be used to sanitize vegetables without affecting their appearance.
\end{abstract}

Keywords: Lactuca sativa, acetic acid, sanitization.

\section{RESUMO} alface

Ação sanitizante de vinagre triplo sobre Escherichia coli em

Protocolos de sanitização de hortaliças utilizam cloro, que apresenta efeitos adversos sobre o meio ambiente e na produção de compostos cancerígenos. Uma alternativa para substituir o cloro é o uso do ácido acético, devido à disponibilidade na forma de vinagre e por não apresentar riscos à saúde humana. O trabalho teve como objetivo avaliar a ação do fermentado acético de álcool com $130 \mathrm{~g}$ $\mathrm{L}^{-1}$ de acidez total, expressa em ácido acético, para uso na sanitização de alfaces. A escolha deste fermentado é justificada por ser um produto de baixo preço e disponível no mercado brasileiro. A concentração inibitória mínima e a concentração bactericida mínima (concentração que eliminou a bactéria) para Escherichia coli foi de 2,5 e $15 \mathrm{~g} \mathrm{~L}^{-1}$ de acidez total, respectivamente. Amostras de alface artificialmente contaminadas com suspensões de $E$. coli e amostras com contaminação de origem foram lavadas com água e imersas em solução com $15 \mathrm{~g} \mathrm{~L}^{-1}$ de ácido acético, por 15 minutos. Esse tempo foi adequado para a redução da contagem de E. coli nas amostras artificialmente contaminadas e na contagem de coliformes totais nas amostras com contaminação de origem. Nenhuma alteração visual das folhas de alface foi observada, indicando que a concentração de $15 \mathrm{~g} \mathrm{~L}^{-1}$ de acidez total pode ser utilizada na sanitização da hortaliça sem prejuízo à sua aparência.

Palavras-chave: Lactuca sativa, ácido acético, sanitização.

Received on April 4, 2017; accepted on May 9, 2018

F oodborne diseases are still a public health problem, and the supply of safe food products has been a constant concern for government health agencies, epidemiological surveillance agencies, and the food industry.

Lettuce (Lactuca sativa) is one of the most consumed vegetables in salads in Brazil. Chlorinated compounds are widely used to sanitize lettuce due to low cost and recommendations of the National Agency of Sanitary Surveillance (ANVISA). The formation of trihalomethanes from chlorinated sanitizers, however, is a cause for concern, as these compounds are carcinogenic. Sanitization alternatives that provide economic and safety benefits by replacing chlorine are of interest.

Acetic acid, produced by fermentation of ethanol by acetic acid bacteria, may be an alternative to chlorine in food sanitization. Acetic acid is the main component of vinegar and can be produced by Acetobacter spp. fermentation of fruit must, honey, cereals, hydroalcoholic mixtures, and vegetables (Spinosa et al., 2015). An important characteristic of vinegar is its low toxicity. Moreover, its use as sanitizer does not alter the taste or smell of foods (Nascimento et al., 2003).

According to Brazilian legislation, the product of acetic fermentation of a hydroalcoholic mixture containing potable ethanol of agricultural origin is denominated alcohol vinegar. Vinegar with volatile acidity over $12 \mathrm{~g}$ of acetic acid per $100 \mathrm{~mL}$ is classified as triple and called triple-strength vinegar. The product of acetic fermentation of ethanol produced from one or more cereals is denominated cereal vinegar (BRASIL, 2012). 
Brazilian industries have sufficient capacity to meet the demand for diversified products based on vinegar. Triple-strength vinegar is commercialized in the Brazilian market for $\$ 0.15 / \mathrm{L}$ (FOB, Free On Board). Noteworthy, vinegar production facilities have a low impact on the environment (ANAV, 2015).

The aim of this study was to evaluate the efficiency of triple-strength vinegar for sanitization of artificially contaminated lettuce with Escherichia coli and naturally contaminated lettuce with total coliforms and E. Coli determining the minimum inhibitory concentration (MIC) and the minimum bactericidal concentration (MBC) using the macrodilution method.

\section{MATERIAL AND METHODS}

Twenty-seven crisphead lettuce heads were randomly obtained and purchased at different commercial establishments in Londrina, in different weeks from October to December 2014. The vegetables were marketed as products grown by conventional agricultural methods.

Triple-strength alcohol vinegar was provided by Tecnologia em Saúde, Indústria e Comércio de Alimentos Ltda., Assis, São Paulo, Brazil. The vinegar was produced by biological fermentation of alcohol. Its total titratable acidity expressed as acetic acid was $130 \mathrm{~g} \mathrm{~L}^{-1}$, and its $\mathrm{pH}$ was 2.50 .

Alcohol vinegar and cereal vinegar were purchased from commercial establishments in Londrina. Alcohol vinegar and cereal vinegar presented pH 2.3 and 2.6, respectively, and total titratable acidity expressed as acetic acid was $40 \mathrm{~g} \mathrm{~L}^{-1}$.

\section{Production of E. coli suspension}

E. coli ATCC 25922 cephae was inoculated into brain heart infusion (BHI) and incubated for $24 \mathrm{~h}$ at $35 \pm 2^{\circ} \mathrm{C}$. Serial dilutions were performed in 1 $\mathrm{g} \mathrm{L}^{-1}$ peptone water (Himedia). and put on MacConkey agar (Himedia) to determine bacterial counting (log CFU/ $\mathrm{mL})$.

Determination of the minimum concentration to inhibit (MIC) $E$. coli growth

The MIC of triple-strength alcohol vinegar, and cereal vinegar against $E$. coli was determined by microdilution in tubes. Aliquots of $100 \mu \mathrm{L}$ of $E$. coli suspension containing approximately $6 \log \mathrm{CFU} / \mathrm{mL}$ were added to tubes containing $\mathrm{BHI}$ and vinegar at final concentrations of $0,2.5,5.0,10.0$, $15.0,20.0$, or $40.0 \mathrm{~g} \mathrm{~L}^{-1}$ total acidity in a final volume of $5 \mathrm{~mL}$. After $15 \mathrm{~min}$, $5 \mathrm{~mL}$ of BHI was added to all tubes. Tubes were incubated at $35^{\circ} \mathrm{C}$ for 24 h. MIC was determined in the tube with no turbidity and with the lowest concentration of acetic acid, that is, the minimum concentration that did not allow bacterial growth.

Determination of the minimum bactericidal concentration (MBC) of vinegar

The determination of MBC of vinegar against $E$. coli was performed by plate counting using MacConkey solid medium. Subsequent to the determination of $\mathrm{MIC}, 10 \mu \mathrm{L}$ aliquots from the test tubes containing $E$. coli and vinegar at different concentrations were inoculated onto MacConkey agar plates. After $24 \mathrm{~h}$ of incubation, MBC was determined as the lowest concentration of acetic acid that completely inhibited E. coli growth.

Efficiency evaluation of the sanitization procedure using triplestrength vinegar on artificially contaminated lettuce leaves with $E$. coli

Six lettuce heads were analyzed individually, representing six replicates of the sanitization procedure. From each lettuce head, the inner and outer leaves were discarded and two $25 \mathrm{~g}$ portions of leaves were weighed. The two portions, identified as A and B, were contaminated with $4 \mathrm{~mL}$ each of $E$. coli suspension containing approximately $6 \log \mathrm{CFU} /$ $\mathrm{mL}$. The suspension was randomly distributed over the leaves using a pipette. After the leaves had dried at room temperature for 3 to $4 \mathrm{~h}$, the units of $E$. coli on portion A were counted. Portion B leaves were immersed for $15 \mathrm{~min}$ in a triple-strength vinegar solution containing $15 \mathrm{~g} \mathrm{~L}^{-1}$ acetic acid, considered the MBC. Portion B leaves were washed with sterile distilled water and centrifuged in a centrifuge suitable for handling leafy vegetables. E. coli counts were then determined.

Portions A (not sanitized) and B (sanitized) were homogenized separately in $50 \mathrm{~mL}$ of $1 \mathrm{~g} \mathrm{~L}^{-1}$ buffered peptone water, and serial dilutions from $10^{-2}$ to $10^{-4}$ were carried out in $1 \mathrm{~g} \mathrm{~L}^{-1}$ buffered peptone water. Subsequently, $100 \mu \mathrm{L}$ of each dilution was plated on MacConkey agar medium in duplicate. Colonies were counted after $24 \mathrm{~h}$ of incubation at $35 \pm 2^{\circ} \mathrm{C}$.

Evaluation of the efficiency of sanitization procedure using triplestrength vinegar on naturally contaminated lettuce leaves

For this analysis, 31 lettuce heads were purchased commercially in Londrina, and analyzed individually. Three $25 \mathrm{~g}$ portions of leaves were collected from each lettuce head and labelled as A, B, and C. Portions B and $C$ were washed under chlorinated running water. Portion $\mathrm{C}$ was immersed in a triple-strength vinegar solution (15 $\mathrm{g} \mathrm{L}^{-1}$ acetic acid) for $15 \mathrm{~min}$; the leaves were then washed in sterile distilled water and centrifuged in a centrifuge suitable for handling leafy vegetables. The most probable numbers (MPN) of total coliforms and $E$. coli on portions $\mathrm{A}, \mathrm{B}$, and $\mathrm{C}$ were determined by the multiple-tube fermentation technique (Silva et al., 2007).

Determination of total titratable acidity of vinegar

To determine total titratable acidity, $1 \mathrm{~mL}$ of triple-strength vinegar and two drops of a $10 \mathrm{~g} \mathrm{~L}^{-1}$ phenolphthalein solution were added to a $100 \mathrm{~mL}$ Erlenmeyer flask. Titration was performed with $0.1 \mathrm{M}$ sodium hydroxide until the solution turned red. Each mL of sodium hydroxide solution corresponded to $6 \mathrm{~g} \mathrm{~L}^{-1}$ total titratable acidity expressed as acetic acid $\left(\mathrm{H}_{3} \mathrm{CCOOH}\right)$ (Spinosa et al., 2015).

\section{Statistical analysis}

E. coli counts on the six artificially contaminated lettuce samples were converted into decimal logarithms $(\log \mathrm{CFU} / \mathrm{mL})$. Data were submitted to statistical analysis in Microsoft Excel 2013. Student's $t$-test was used 
to determine whether $E$. coli counts before and after sanitization with triple-strength vinegar differed at 5\% significance level.

\section{RESULTS AND DISCUSSION}

The concentrations of triple-strength vinegar, alcohol vinegar, and cereal vinegar used for determining MIC and MBC were 0, 2.5, 5.0, 10.0, 15.0, 20.0, and $40.0 \mathrm{~g} \mathrm{~L}^{-1}$ total titratable acidity expressed as acetic acid. The addition of $5 \mathrm{~mL}$ of BHI after $15 \mathrm{~min}$ of exposure of the $E$. coli inoculum to vinegar was essential for the determination of MIC and $\mathrm{MBC}$ values. Without this step, it was not possible to recover viable $E$. coli cells, independently of the concentration of acetic acid used in the experiment. This procedure allowed the recovery of $E$. coli cells damaged by the action of vinegar after 15 min sanitization probably because of dilution of the acetic acid present in the medium at the end of the experiment. The MIC and $\mathrm{MBC}$ values of the vinegars against $E$. coli were respectively 2.5 and $15.0 \mathrm{~g}$ $\mathrm{L}^{-1}$ total titratable acidity expressed as acetic acid.

A significant reduction was observed in the mean $E$. coli count of artificially contaminated lettuce leaves after sanitization using $15 \mathrm{~g} \mathrm{~L}^{-1}$ acetic acid solution prepared with triple-strength vinegar (Table 1).

Nascimento et al. (2003) reported similar results to those of the present study. The authors compared the efficiency of acetic acid, chlorine, and peracetic acid for sanitizing lettuce and recommended the use of $20 \mathrm{~g} \mathrm{~L}^{-1}$ acetic acid for $15 \mathrm{~min}$ by immersion. Other studies have also evaluated the bactericidal action of acetic acid on E. coli using artificially contaminated lettuce, but assays were performed with different concentrations from those used in the present study. Park et al. (2011) tested the antimicrobial efficiency of different organic acids and obtained a $1.57-\log \mathrm{CFU} / \mathrm{g}$ reduction in $E$. coli count using $20 \mathrm{~g} \mathrm{~L}^{-1}$ acetic acid for 5 min, a result similar to that reported by Akbas \& Olmez (2007), a 1.5-log $\mathrm{CFU} / \mathrm{g}$ reduction after $2 \mathrm{~min}$ of exposure of lettuce leaves to $10 \mathrm{~g} \mathrm{~L}^{-1}$ acetic acid solution. Vijayakumar \& Wolf-Hall (2002) evaluated the effect of apple vinegar, white vinegar, chlorine, and lemon juice against $E$. coli on lettuce. The most effective result was achieved with white vinegar at $19 \mathrm{~g} \mathrm{~L}^{-1}$ total titratable acidity expressed as acetic acid. There was a 5-log reduction in $E$. coli counts when samples were immersed in white vinegar solution for $5 \mathrm{~min}$ under shaking or for $10 \mathrm{~min}$ without shaking.

Bjornsdottir et al. (2006) stated that many factors affect the antimicrobial activity of organic acids, such as $\mathrm{pH}$, acid concentration, bacterial species, and the environment of bacterial cultures. Several studies have been carried out on the bactericidal action of acetic acid against other pathogenic bacteria, using varied vegetables and acetic acid concentrations. Reductions of up to $1.4 \mathrm{log} \mathrm{CFU} / \mathrm{g}$ of Listeria monocytogenes were observed in artificially contaminated lettuce and leafy salads sanitized with acetic acid solutions at concentrations ranging from 5 to $10 \mathrm{~g} \mathrm{~L}^{-1}$ (Porto \& Eiroa, 2006; Samara \& Koutsoumanis, 2009; Nastou et al., 2012; Ramos et al., 2014). A reduction of $1.74 \mathrm{log} \mathrm{CFU} / \mathrm{g}$ in Salmonella spp. count was obtained by sanitizing alfalfa and lettuce with 50 and $20 \mathrm{~g} \mathrm{~L}^{-1}$ acetic acid solution for $10 \mathrm{~min}$, respectively (Weissinger \& Beuchat, 2000; Park et al., 2011). Karapinar \& Gonul (1992) achieved a 7-log CFU/ $\mathrm{mL}$ reduction in Yersinia enterocolitica counts using $20 \mathrm{~g} \mathrm{~L}^{-1}$ acetic acid.

Other important factors to be considered in studies that evaluate food sanitization using vinegar are the food's inherent characteristics. Differences in bacterial microenvironments formed on the surfaces of different vegetables should be taken into consideration when extrapolating the findings of this study to other foods. Washing processes may not be as efficient when there are cracks, crevices, or interstices on food surfaces (Ramos et al., 2014).

Studies that tested the performance of $50 \mathrm{~g} \mathrm{~L}^{-1}$ acetic acid in the sanitization of vegetables reported negative changes to the sensorial characteristics of the product (Chang \& Fang, 2007; Wu et al., 2000). The results obtained in the present study using triple-strength vinegar containing $15 \mathrm{~g} \mathrm{~L}^{-1}$ acetic acid are satisfactory from an application point of view, as the higher the concentration of acetic acid in the sanitizing solution, the greater the probability of sensorial changes in vegetables.

Most of the studies on the efficacy of sanitizing agents on fruits and vegetables were carried out with artificially contaminated products. In the present study, in addition to the analysis of lettuce artificially contaminated with E. coli, naturally contaminated lettuce leaves were analyzed. Table 2 shows the results of $\log$ MPN/g of total coliforms on lettuce samples. Contamination ranged from 1.63 to $3.38 \log \mathrm{MPN} / \mathrm{g}$. Brazilian legislation does not establish limits for total coliforms, and their presence is natural in fresh vegetables because of the type of cultivation. Berbari et al. (2001) stated, however, that total coliform counts can be used

Table 1. E. coli counts in artificially contaminated lettuce leaves before and after sanitization with vinegar (15 $\mathrm{g} \mathrm{L}^{-1}$ total titratable acidity expressed as acetic acid). Londrina, UEL, 2014.

\begin{tabular}{lcc}
\hline Sample & $\begin{array}{c}E \text { c coli count before sanitization } \\
(\log \mathbf{C F U} / \mathbf{g})\end{array}$ & $\begin{array}{c}\boldsymbol{E} \text { c coli count after sanitization } \\
(\log \mathbf{C F U} / \mathbf{g})\end{array}$ \\
\hline 1 & $2.99 \mathrm{a}$ & $2.11 \mathrm{~b}$ \\
2 & $3.00 \mathrm{a}$ & $0.60 \mathrm{~b}$ \\
3 & $3.04 \mathrm{a}$ & $0.78 \mathrm{~b}$ \\
4 & $3.36 \mathrm{a}$ & $0.00 \mathrm{~b}$ \\
5 & $3.36 \mathrm{a}$ & $0.78 \mathrm{~b}$ \\
6 & $3.88 \mathrm{a}$ & $0.30 \mathrm{~b}$ \\
\hline Mean & $3.27 \pm 0.31^{\mathrm{a}}$ & $0.76 \pm 0.66^{\mathrm{b}}$ \\
\hline
\end{tabular}

Counts and mean counts followed by different letters differ significantly $(\mathrm{p} \leq 0.05)$. 
Table 2. Total coliform counts in naturally contaminated lettuce leaves ${ }^{2}$ and count reductions after washing samples under running chlorinated water ${ }^{3}$ and after washing samples under running chlorinated water and sanitizing with vinegar solution $\left(15 \mathrm{~g} \mathrm{~L}^{-1}\right)^{4}$ (total titratable acidity expressed as acetic acid). Londrina, UEL, 2014.

\begin{tabular}{|c|c|c|c|}
\hline Sample $^{1}$ & $\begin{array}{c}\text { Total coliform } \\
\text { count }(\log \text { MPN/g) }\end{array}$ & $\begin{array}{l}\text { Total coliform count } \\
\text { after washing (log } \\
\text { MPN/g) }\end{array}$ & $\begin{array}{c}\text { Total coliform count } \\
\text { after washing and } \\
\text { sanitizing (log MPN/g) }\end{array}$ \\
\hline 1 & 2.38 & 0.00 & 2.38 \\
\hline 2 & 2.38 & 1.75 & 2.38 \\
\hline 3 & 2.38 & 1.41 & 2.02 \\
\hline 4 & 2.38 & 1.93 & 2.02 \\
\hline 5 & 1.66 & 1.49 & 1.66 \\
\hline 6 & 2.38 & 1.41 & 2.38 \\
\hline 7 & 2.38 & 1.41 & 1.75 \\
\hline 8 & 2.38 & 0.34 & 2.02 \\
\hline 9 & 2.38 & 0.72 & 1.20 \\
\hline 10 & 2.38 & 2.20 & 2.38 \\
\hline 11 & 2.38 & 1.20 & 1.41 \\
\hline 12 & 1.66 & 1.03 & 2.06 \\
\hline 13 & 2.04 & 1.07 & 2.04 \\
\hline 14 & 2.38 & 1.41 & 1.75 \\
\hline 15 & 2.38 & 1.06 & 2.38 \\
\hline 16 & 1.63 & 0.79 & 1.03 \\
\hline 17 & 1.97 & 1.37 & 1.97 \\
\hline 18 & 2.66 & 1.34 & 2.66 \\
\hline 19 & 3.38 & 2.54 & 2.78 \\
\hline 20 & 3.04 & 2.44 & 3.04 \\
\hline 21 & 2.32 & 0.69 & 1.72 \\
\hline 22 & 3.04 & 2.09 & 3.04 \\
\hline 23 & 3.04 & 0.87 & 2.44 \\
\hline 24 & 3.38 & 1.41 & 3.38 \\
\hline 25 & 2.32 & 1.00 & 1.72 \\
\hline 26 & 3.04 & 0.00 & 2.09 \\
\hline 27 & 3.38 & 0.73 & 2.02 \\
\hline 28 & 3.04 & 0.39 & 1.41 \\
\hline 29 & 3.38 & 0.73 & 3.38 \\
\hline 30 & 3.04 & 1.68 & 3.04 \\
\hline 31 & 3.38 & 1.00 & 2.78 \\
\hline
\end{tabular}

${ }^{1}$ Samples purchased at different commercial establishments in Londrina, Paraná, Brazil.

as an indicator of hygiene and are considered high when above $5.0 \mathrm{log}$ $\mathrm{MPN} / \mathrm{g}$ in foods. All samples analyzed in this study were contaminated with total coliforms but none showed counts greater than $5.0 \log$ MPN/g, as opposed to other studies, in which high counts of total coliforms were identified in the samples (Cabrini et al., 2002; Oliveira $\&$ Figueiredo, 2006).

The results of the sanitization of naturally contaminated lettuce using the triple-strength vinegar solution containing $15 \mathrm{~g} \mathrm{~L}^{-1}$ acetic acid are in Table 2. A reduction of 1.03 to $3.38 \mathrm{log}$ $\mathrm{MPN} / \mathrm{g}$ in total coliform bacteria was observed. This reduction was greater than that obtained by washing samples in running chlorinated water (0-2.5 log $\mathrm{MPN} / \mathrm{g}$ ).

Statistical analysis was performed only on the results of E. coli counts of the six artificially contaminated lettuce samples before and after vinegar sanitization (Table 1). The results of total coliform counts in naturally contaminated lettuce before and after sanitization (Table 2) were not submitted to statistical analysis because of the great variation between initial and final bacterial counts. The purpose was to present the reduction in bacterial count promoted by the treatments as raw data.

Other studies also evaluated the performance of acetic acid solutions in the sanitization of naturally contaminated vegetables. Oliveira et al. (2012) reported a reduction of 2.09 $\log \mathrm{CFU} / \mathrm{g}$ in total coliforms on lettuce using $8 \mathrm{~g} \mathrm{~L}^{-1}$ acetic acid. Nascimento et al. (2003) used $20 \mathrm{~g} \mathrm{~L}^{-1}$ acetic acid and obtained a 3.57-log CFU/g reduction in mesophilic aerobes on lettuce samples. Fantuzzi et al. (2004) obtained a reduction of $1.8 \log \mathrm{CFU} / \mathrm{g}$ in mesophilic aerobes after sanitizing cabbage samples for $10 \mathrm{~min}$ with $10 \mathrm{~g}$ $\mathrm{L}^{-1}$ acetic acid at room temperature.

A total of $23(74.2 \%)$ of the 31 naturally contaminated lettuce samples analyzed in this study were contaminated with $E$. coli before washing with water. All counts were below the limit established by Brazilian legislation and ranged from 0.4 to $46 \log \mathrm{MPN} / \mathrm{g}$. $E$. coli was isolated from nine of the 23 contaminated samples after sanitization with running chlorinated water and from one sample after sanitization using triple-strength vinegar solution containing $15 \mathrm{~g} \mathrm{~L}^{-1}$ acetic acid.

Washing lettuce leaves under running chlorinated water and immersing them in $15 \mathrm{~g} \mathrm{~L}^{-1}$ acetic acid solution for $15 \mathrm{~min}$ promoted a reduction in $E$. coli counts on artificially contaminated samples and a reduction in total coliform counts in naturally contaminated samples. There were no visual changes in treated lettuce leaves, which indicates that vinegar at $15 \mathrm{~g} \mathrm{~L}^{-1}$ total titratable acidity can be used to sanitize vegetables without affecting their appearance.

\section{ACKNOWLEDGMENTS}

The authors thank the Coordination for the Improvement of Higher 
Education Personnel (CAPES) for granting a master's scholarship to Giovanna Cavagnari de Souza and the National Council for Scientific and Technological Development (CNPq) for the financial support provided.

\section{REFERENCES}

AKBAS, MY; OLMEZ, H. 2007. Inactivation of Escherichia coli and Listeria monocytogenes on iceberg lettuce by dip wash treatments with organic acids. Letters in Applied Microbiology 44: 619-624

ANAV - Associação Nacional das Indústrias de Vinagre. 2015. Available at http://www.anav. com.br/. Accessed November 15, 2015

BERBARI, SAG, PASCHOALINO, JE, SILVEIRA, NFA. 2001. Efeito do cloro na água de lavagem para desinfeção de alface minimamente processada. Ciência e Tecnologia de Alimentos 21: 197-201.

BJORNSDOTTIR, K, BREIDIT, JR F, MCFEETERS, RF. 2006. Protective effect of organic acids on survival of Escherichia coli O157:H7 in acidic environments. Applied and Environmental Microbiology 72: 660-664.

BRASIL. Ministério da Agricultura, Pecuária e Abastecimento. MAPA. Instrução Normativa $\mathrm{n}^{\mathrm{o}}$ 6, de 3 de abril de 2012. Estabelece os padrões de identidade e qualidade e a classificação dos fermentados acéticos.

CABRINI, KT; SIVIERO, AR; HONORIO, EF; OLIVEIRA, LFC; VENANCIO, PC. 2002. Pesquisa de coliformes totais e E. coli em alfaces (Lactuca sativa) comercializadas na cidade de Limeira, SP, Brasil. Revista Higiene Alimentar 16: 92-94.

CHANG, JM; FANG, TJ. 2007. Survival of
Escherichia coli O157:H7 and Salmonella enterica serovar Typhimurium in iceberg lettuce and the antimicrobial effect of rice vinegar against E. coli O157:H7. Food Microbiology 24: 745-751.

FANTUZZI, E; PUSCHMANN, R; VANETTI, MCD. 2004. Microbiota contaminante em repolho minimamente processado. Ciência e Tecnologia dos Alimentos 24: 207-211.

KARAPINAR, M, GONUL, SA. 1992. Effects of sodium bicarbonate, vinegar, acetic and citric acids on growth and survival of Yersinia enterocolitica. International Journal of Food Microbiology 16: 343-347.

NASCIMENTO, MS; SILVA, N; CATANOZI, MPLM. 2003. Emprego de sanitizantes na desinfecção de vegetais. Revista Higiene Alimentar 17: 42-46.

NASTOU, A; RHOADES, J; SMIRNIOTIS, P; MAKRI, I; KONTOMINAS, M; LIKOTRAFITI, E. 2012. Efficacy of household washing treatments for the control of Listeria monocytogenes on salad vegetables. International Journal of Food Microbiology 159: 247-253.

OLIVEIRA, M; VIÑAS, I; USALL, J; ANGUERA, M; ABADIAS, M. 2012. Presence and survival of $E$. coli $\mathrm{O} 157: \mathrm{H} 7$ on lettuce leaves and in soil treated with contaminated compost and irrigation water. International Journal of Food Microbiology 156: 133-140.

OLIVEIRA, MLS; FIGUEIREDO, EL. 2006. Análise microbiológica de alface (Lactuca sativa) e tomate (Solanum lycopersicum) comercializados em feiras-livres da cidade de Belém, Pará. Revista Higiene Alimentar 20: 96-101.

PARK, SH.; CHOI, MR; PARK, JW; PARK, KH; CHUNG, MS; RYU, S; KANG, DH. 2011. Use of organic acids to inactive Escherichia coli O157:H7, Salmonella typhimurium and Listeria monocytogenes on organic fresh apples and lettuce. Journal of Food Science
76: M293-M298.

PORTO, E; EIROA, MNU. 2006. Avaliação da eficiência de sanificantes e do uso de atmosferas modificadas sobre Listeria monocytogenes inoculada em alfaces (Lactucca sativa). Brazilian Journal of Food Technology 9: 177-183.

RAMOS, B; TEIXEIRA, P; BRANDÃO, TRS; SILVA, CLM. 2014. Balsamic vinegar from Modena: An easy and effective approach to reduce Listeria monocytogenes from lettuce. Food Control 42: 38-42.

SAMARA, A; KOUTSOUMANIS, KP. 2009. Effect of treating surfaces with acidulants on the behaviour of Listeria monocytogenes during storage at 5 and 20 degrees $\mathrm{C}$ and subsequent exposure to simulated gastric fluid. International Journal of Food Microbiology 129: 1-7.

SILVA, N; JUNQUEIRA, VCA; SILVEIRA, NFA; TANIWAKI, MH; SANTOS, RFS; GOMES, RAR. 2007. Manual de métodos de análise microbiológica de alimentos. 3ed. São Paulo: Livraria Varela. 536p.

SPINOSA, WA; SANTOS JÚNIOR, V; GALVAN, D; FIORIO, JL; GOMEZ, RJHC. 2015. Vinegar rice (Oryza sativa L.) produced by a submerged fermentation process from alcoholic fermented rice. Food Science and Technology 35: 196-201.

VIJAYAKUMAR, C; WOLF-HALL, CE. 2002. Evaluation of household sanitizers for reducing levels of Escherichia coli on iceberg lettuce. Journal of Food Protection 65: 1646-1650.

WEISSINGER, WR; BEUCHAT, LR. 2000. Comparison of aqueous chemical treatments to eliminate Salmonella on alfafa seed. Journal of Food Protection 63: 1475-1482.

WU, FM; DOYLE, MP; BEUCHAT, LR; WELLS, JG; MINTZ, ED; SWAMINATHAN, B. 2000. Fate of Shigella sonnei on parsley and methods of disinfection. Journal of Food Protection 63: $568-572$. 